\title{
E-WoM: Pengaruhnya terhadap Keputusan Pembelian Tamu Restoran di Bandung Utara
}

\author{
Taufansyah Firdaus \\ STIEPAR Yapari Aktripa \\ taufansyahfirdaus@gmail.com \\ Taufik Abdullah \\ Universitas Pendidikan Indonesia \\ taufikabdullah@upi.edu
}

\begin{abstract}
The Development of information and technology has entered various elements of life, including human lifestyle when visiting restaurants. Some trends in the younger generation when visiting restaurants in Bandung, they often check in on social media, take selfie pictures with the interior design of the restaurant as the background, and the most common activity is taking photo of food or beverage products of the restaurant. furthermore, they upload the pictures to various social media. If referring to the literature, these activities could be classified as electronic word of mouth (e-WOM). The purpose of this study was to determine the role of e-word of mouth to increase the purchasing decision of restaurants in North Bandung. This is an explanatory study. The population in this study were restaurant's customers in North Bandung so that the population was infinite. Thus the sampling technique used was quota sampling technique with a target of 100 respondents. The Data analysis technique used is multiple regression analysis. This research is expected to be an input for providers of food service business, particularly restaurants for consideration in conducting marketing activities in order to increase the sales of food and drink. The results of this research that there is a significant influence of the e-word of mouth on restaurant's customers purchase decision in North Bandung.
\end{abstract}

Keywords- electronic word of mouth; purchase decision

\section{Pendahuluan}

Seiring pertumbuhan zaman, manusia dituntut untuk terus berkarya dalam hidupnya. Bekerja dengan keras sudah merupakan kewajiban agar manusia dapat sukses dalam kehidupan dunianya. Hal tersebut, memicu manusia untuk melakukan berbagai usaha positifnya mulai dari mengenyam pendidikan, berkerja maupun berwisausaha yang mana kebanyakan kegiatan ini tentunya dilakukan di luar rumah ataupun di luar lingkungan tempat tinggal. Dengan berbagai kegiatan yang begitu padatnya, terdapat suatu kebutuhan mendasar yang harus terus dipenuhi, yaitu kebutuhan akan asupan makanan dan minuman.

Gaya hidup yang telah berubah, membuat manusia tidak lagi sempat untuk selalu menikmati hidangan makanan ataupun minuman yang dibuat di rumah. Banyak yang justru berpendapat bahwa akan lebih efisien untuk memenuhi kebutuhan makan dan minum dengan cara membeli dari berbagai usaha penyedia jasa makanan dan minuman. Hal ini berakibat pada menjamurnya usaha-usaha tersebut dalam berbagai macam bentuk, mulai dari restoran, rumah makan, warung makan, katering, hingga pedagang kaki lima yang menyediakan makanan.

Usaha-usaha tersebut terutama berkembang di kota-kota besar di Indonesia termasuk Bandung. Sebagai kota yang terkenal dengan wisata kulinernya, jumlah restoran tentunya sangat banyak dan seiring waktu terus bertambah. Restoran bermunculan sebagai tempat untuk mendapat hidangan makanan dan minuman dengan suasana yang santai dengan keunikan disain, pelayanan dan produk makanan minumannya. Kebanyakan tamu yang mengunjungi restoran beragam mulai dari para pekerja, keluarga hingga generasi muda.

Seiring dengan berkembangnya teknologi dan informasi, para generasi muda yang mengunjungi restoran tersebut menciptakan suatu trend baru. Hal ini tentunya dipicu karena hampir setiap individu saat ini memiliki telepon genggam pribadi yang memiliki fitur cukup lengkap, yaitu diantaranya terkoneksi dengan internet, GPS, kemampuan foto yang memadai, serta terinstall software media sosial. Bahkan banyak restoran yang juga menyediakan fasilitas 
wifi gratis apabila konsumen telah membeli produknya.

Generasi muda tersebut memanfaatkan kemampuan gadget-nya ketika berada di restoran. Fenomena yang kerap terjadi adalah melakukan check in ketika tiba di restoran, berfoto selfie, dan yang paling sering terjadi adalah memotret makanan ataupun minuman dengan telepon genggam yang kemudian mengunggahnya di media sosial seperti Facebook, Twitter, Path ataupun Instagram.

Telah banyak artikel di media online yang membahas tentang fenomena di atas, salah satunya Ananda (2013, 21 Oktober) dalam www.merdeka.com, menyatakan bahwa "Kebiasaan baru orang-orang saat ini adalah memotret makanan mereka sebelum makan dan mengunggahnya ke jejaring sosial seperti Facebook atau Instagram". Bahkan Hapsari (2013, 08 Mei), dalam food.detik.com memberi nama kepada salah satu kegiatan tersebut, berikut yang dikutip dalam berita tersebut, "foodstagram dideskripsikan kegiatan memotret makanan dan mengunggahnya ke berbagai media sosial termasuk Instagram. Banyak orang gandrung melakukan foodstagram".

Menurut Dr. Taylor, psikiater dari Women College Hospital, University of Toronto, Kanada. "Beberapa orang keluar rumah untuk makan, bukan karena memang membutuhkan makanan. Justru hanya demi interaksi di media sosial. Apa yang dimakan, kapan mengunjunginya dan kapan kembali ke tempat tersebut" Nugraheni (2013, 09 Mei) dalam life.viva.co.id. Fenomena yang sangat booming ini tujuan dilakukannya pun mulai bergeser, tamu restoran yang awalnya hanya ingin memberikan informasi tentang tempat makanan dan item makanan yang di jual sebagai bahan rekomendasi. Bagi beberapa individu mulai berubah fungsinya, sehingga ada kecenderungan mengunjungi restoran untuk mengincar prestise, dengan menggunggah foto makanan yang harganya mahal, atau check in di restoran yang terkenal.

Fenomena ini secara tidak langsung merupakan kegiatan $e$-word of mouth dimana ketika seseorang check in di suatu restoran dan kemudian memotret dan mengunggah foto makanan atau minumannya, apalagi disertai komentar maka orang lain yang melihat dapat tertarik untuk juga datang ke restoran tersebut, hal ini tentunya dapat menjadi iklan gratis bagi perusahaan. Seperti yang dijelaskan oleh Song, Hwang, Kim, \& Kwak. (2013:457). " $e-W o M$ marketing can be considered as a social exchange activity that involves the sharing of information through internet-based community networks". Jika diterjemahkan maka e-WoM
Marketing dapat diartikan sebagai kegiatan pertukaran sosial yang melibatkan aktivitas berbagi informasi melalui jaringan komunitas berbasis internet.

Fenomena mengenai e-word of mouth yang tengah terjadi di kehidupan masyarakat muda khususnya di Bandung dinilai sangat menarik untuk dikaji, khususnya mengenai dampaknya terhadap keinginan orang untuk mengunjungi restoran yang item makanan minumannya terlihat di media sosial. Sehingga studi ini dilakukan dengan tujuan untuk mengetahui peranan kegiatan e-word of mouth dalam meningkatkan keputusan pembelian tamu restoran di Bandung Utara.

\section{KAJIAN PUSTAKA}

\section{A. Konsep Electronic Word of Mouth}

Kegiatan word of mouth telah sejak lama diketahui merupakan salah satu kegiatan promosi yang paling efektif dalam rangka mempengaruhi calon konsumen untuk membeli suatu produk. Wu \& Wang (2011:450) menyatakan definisi word of mouth sebagai berikut, "WOM is oral person-to-person communication between a receiver and a sender, which involves a product, service, or brand". Word of mouth adalah komunikasi secara langsung dari individu ke individu lainnya, antara pengirim dan penerima pesan, yang terdiri dari produk, pelayanan atau merek.

Perkembangan teknologi dan informasi, membuat kegiatan word of mouth memasuki level baru. Kegiatan ini sudah mulai marak digunakan di dunia maya, seperti yang diungkapkan oleh Cheung, Lee and Rabjohn (2008:230-231). "It can also be considered as the extension of traditional interpersonal communication into the new generation of cyberspace". E-WOM dapat juga diartikan sebagai lanjutan/perpanjangan dari komunikasi antar manusia secara tradisional menjadi generasi baru dalam dunia maya. Seperti yang telah dijelaskan di atas, bentuk kegiatan word of mouth yang baru dimana kegiatannya dilakukan di dunia maya disebut dengan e-word of mouth.

Beberapa ahli telah mendefinisikan e-word of mouth salah satunya adalah Kietzmann dan Canhoto (2013),

E-WoM refers to any statement based on positive, neutral, or negative experiences made by potential, actual, or former consumers about a product, service, brand, or company, which is made available to a multitude of people and institutions via the Internet (through web sites, social networks, instant messages, news feeds...). 
E-WoM mengacu kepada suatu pernyataan berbasis pengalaman positif, netral, atau negatif dibuat oleh konsumen yang potensial, nyata atau mantan konsumen mengenai sebuah produk, pelayanan, merek, atau perusahaan, yang dapat diketahui oleh orang dan institusi melalui internet (melalui website, media sosial, pesan instan, Berita,...). Lain halnya menurut $\mathrm{Wu} \&$ Wang (2011:448), "Electronic word-of-mouth (eWOM) refers to the knowledge exchange consumers carry out online. This exchange has a direct relationship on customer loyalty, which in turn affects overall value of the company". Electronic Word-of-Mouth (e-WOM) mengarah kepada suatu pertukaran pengetahuan yang dilakukan konsumen secara online. Pertukaran ini memiliki hubungan langsung terhadap loyalitas pelanggan, yang selanjutnya mempengaruhi keseluruhan nilai perusahaan.

Penggunaan istilah e-word of mouth ini mengalami perubahan oleh berbagai ahli. Vilpponen, Winter, dan Sundqvist (2006:64) mencoba merangkum berbagai istilah lain dari e-word of mouth yang memiliki pengertian hampir sama, diantaranya interactive marketing, viral marketing, internet communication, internet word-of-mouth dan word-of-mouse, online feedback mechanisms, stealth marketing, buzz marketing, electronic word-of-mouth communication, interactive atau electronic word-of-mouth advertising, dan electronic referral marketing.

Berbagai istilah lain dari e-word of mouth yang akan dijelaskan adalah mengenai viral marketing, buzz marketing dan online marketing. Dimana menurut Vilpponen, Winter, and Sundqvist (2006:66), "We define viral marketing as word-of-mouth communication in situations where positive network effects prevail and where the role of the influencer is active due to positive network effects". Kami mendefinisikan viral marketing sebagai komunikasi word of mouth dalam situasi dimana efek jaringan yang positif berlaku dan dimana peran pemberi pengaruh adalah aktif disebabkan oleh efek positif jaringannya. Sedangkan buzz marketing menurut Thomas (2004:64) dijelaskan sebagai berikut. "Buzz marketing is defined as the amplification of initial marketing efforts by third parties through their passive or active influence". Dengan kata lain buzz marketing adalah suatu penguatan dari usaha pemasaran awal oleh pihak ketiga melalui pengaruh pasif maupun aktifnya. Sun (2013:2316) menjelaskan mengenai istilah online word of mouth, yaitu:

Online WOM means the consumers communicate information about product quality, service as well as good or bad consuming experience to other consumers in the form of text, voice, image, video or combination of them using online forum, email, search engine and other online platforms.

Online WOM berarti konsumen mengkomunikasikan informasi mengenai kualitas produk, pelayanan termasuk pengalaman baik atau tidak yang dialami konsumen kepada konsumen lainnya dalam bentuk tulisan, suara, gambar, video atau kombinasi keseluruhannya dengan menggunakan forum online, email, mesin pencari dan platform online lainnya.

Penjelasan di atas menunjukkan bahwa banyak istilah electronic word of mouth lain yang diungkapkan ahli, yang secara pengertian adalah hampir sama. Dalam studi ini, dimensi yang digunakan diambil dari definisi electronic word of mouth Litvin, Goldsmith, and Pan (2008:9). "Electronic Word-of-Mouth (e-WOM) can be defined as all informal communications directed at consumers through Internet-based technology related to the usage or characteristics of particular goods and services, or their sellers". Jika diterjemahkan maka, Electronic Word-of-Mouth (e-WOM) dapat didefinisikan sebagai seluruh komunikasi informal yang ditujukan kepada konsumen melalui teknologi berbasis internet yang berhubungan dengan penggunaan atau karakteristik dari barang dan jasa tertentu, atau penjualnya. Sehingga dimensinya adalah characteristic of the goods, characteristic of the services dan characteristic of the sellers.

Beberapa studi telah menunjukkan pengaruh e-word of mouth terhadap keputusan pembelian. Seperti yang diungkapkan oleh Themba dan Mulala (2013:33) yang merangkum penelitian (Reigner, 2007; Kamtarin, 2012; Wu \& Wang, 2011). Berikut pernyataannya "several studies have suggested that eWOM has a positive influence on purchase decisions". Beberapa studi telah menunjukkan bahwa e-word of mouth memiliki pengaruh positif terhadap keputusan pembelian.

\section{B. Konsep Keputusan Pembelian}

Keputusan pembelian menurut Kotler dan Keller (2012:166) adalah sebagai berikut,

Keputusan pembelian adalah sebuah perilaku konsumen dimana konsumen mempunyai keinginan dalam membeli atau memilih suatu produk, berdasarkan pengalaman, dalam memilih, menggunakan dan mengkonsumsi bahkan menginginkan suatu produk. 
Sehingga diketahui bahwa keputusan pembelian merupakan bagian dari perilaku konsumen, yang kegiatannya dilakukan agar dapat terpenuhi kebutuhan ataupun keinginan konsumen itu sendiri. Sesuai dengan yang dipaparkan Hawkins dan Mothersbaugh. (2010:6)

Consumer behavior is the study of individuals, groups or organizations and the process they use to select, secure, use and dispose of products, service, experiences or ideas to satisfy needs and the impacts that these processes have on the consumer and society.

Perilaku konsumen adalah studi mengenai individu, kelompok atau organisasi serta proses yang dilakukan dalam memilih, mengamankan, menggunakan, dan membuang suatu produk, jasa, pengalaman atau ide untuk memenuhi kebutuhan dan dampak dari proses ini terhadap konsumen dan masyarakat.

Menurut Hollensen (2010:114) proses keputusan pada konsumen diawali oleh identifikasi masalah yang selanjutnya diikuti dengan pencarian informasi. Setelah adanya informasi yang memadai maka dilakukan evaluasi dari berbagai alternatif pilihan yang ada. Setelah itu baru ditetapkan suatu keputusan dan dilakukan pembelian. Setelah pembelian terjadi, maka dilanjutkan dengan kegiatan evaluasi kembali mengenai produk dan jasa yang telah dibeli sebagai bahan referensi untuk masa depan.

Selanjutnya untuk mengetahui bagaimana keputusan pembelian tamu restoran di Bandung Utara, maka dimensi yang digunakan adalah dari Kotler dan Armstrong (2012:171) dimana keputusan pembelian diukur melalui respon pembeli tepat ketika diambilnya keputusan pembelian, diantaranya product or service choice, supplier choice, order quantities, delivery terms and times, service terms dan payment.

\section{Metode Penelitian}

Penelitian ini adalah penelitian eksplanatori (explanatory research). Silalahi (2012: 30) menjelaskan bahwa, "penelitian eksplanatori atau eksplanatif atau eksplanasi bertujuan untuk menjelaskan hubungan antara dua atau lebih gejala atau variabel". Variabel dalam penelitian ini adalah Electronic Word of Mouth (X) dan Keputusan Pembelian (Y). Objek penelitian ini adalah restoran di Bandung Utara.

Populasi dalam penelitian ini adalah pelanggan restoran di Bandung Utara. Data tersebut sangat sulit untuk di dapat mengingat banyak restoran yang tidak mencatat jumlah pasti tamu yang datang ke restorannya. Mengingat jumlah populasi yang tidak diketahui. Maka dalam penentuan sampel teknik yang digunakan adalah sampling kuota yang berdasarkan Utama dan Mahadewi (2012: 74)

Sampling kuota adalah metode memilih sampel yang mempunyai ciri-ciri tertentu dalam jumlah atau kuota yang diinginkan. Jumlah subjek yang akan diselidiki ditetapkan lebih dahulu. Jika kuota telah ditentukan mulailah penyelidikan dan tentang siapa yang akan dijadikan responden, terserah kepada team pengumpul data.

Penulis menentukan kuota responden yang harus dipenuhi yaitu sebanyak 100 responden. Angket ataupun kuesioner dioberikan kepada seluruh responden. Kuesioner ini berisi pertanyaan mengenai variabel yang diteliti yaitu Electronic Word of Mouth dan Keputusan Pembelian. Setelah data kuesioner terkumpul, selanjutnya dianalisis menggunakan analisis data deskriptif dan verifikatif dengan menggunakan Koefisien Korelasi Pearson, Koefisien Determinasi dan Analisis Regresi.

\section{HASIL PENELITIAN DAN PEMBAHASAN}

A. Gambaran Kegiatan E-Word of Mouth pada Restoran di Bandung Utara

Kegiatan electronic word of mouth pada dasarnya merupakan aplikasi word of mouth di dunia maya. Kegiatan ini sering kali dilaksanakan dalam situs media sosial, namun tidak tertutup pada situs blog ataupun situs yang menyediakan forum diskusi. Pada studi ini electronic word of mouth dinilai dari tiga dimensi yaitu characteristic of the goods, characteristic of the services serta characteristic of the sellers.

TABEL 1. GAMBARAN KEgIATAN E-WORD OF MOUTH PADA RESTORAN DI BANDUNG UTARA

\begin{tabular}{clcc}
\hline No & \multicolumn{1}{c}{ Dimensi } & Rata-Rata & Kategori \\
\hline 1 & Characteristic of the goods & 3,93 & Baik \\
2 & Characteristic of the services & 3,74 & Baik \\
3 & Characteristic of the sellers & 3,73 & Baik \\
\hline & & 3,78 & Baik \\
\hline
\end{tabular}

Dari tabel 1 diketahui bahwa kegiatan electronic word of mouth dalam penyebaran informasi produk lebih tinggi dibandingkan dengan jasa dan penjualnya. Produk menjadi yang tertinggi karena memang generasi muda banyak yang posting di media sosial tentang produk makanan dan minuman. Baik itu mengenai kualitas produk, deskripsi produk hingga pada gambar hasil foto yang diambil secara personal oleh pelanggan. Perihal karakteristik pelayanan dan penjual memang 
jarang kali tersampaikan, yang biasanya tersampaikan adalah hanya lokasi dan nama usaha jasa penyediaan makanan dan minuman. Karena fitur media sosial yang digunakan adalah fitur check in sehingga diketahui informasi tersebut. Dari tabel di atas juga dapat diketahui bahwa kegiatan electronic word of mouth akan restoran di Kota Bandung Utara telah terlaksana dengan baik.

B. Gambaran Keputusan Pembelian Tamu

Restoran di Bandung Utara

Keputusan pembelian dinilai dari enam dimensi yang dapat terlihat pada tabel berikut ini.

TABel 2. Gambaran Keputusan Pembelian TAMU RESTORAN DI BANDUNG UTARA

\begin{tabular}{clcc}
\hline No & \multicolumn{1}{c}{ Dimensi } & Rata-Rata & Kategori \\
\hline 1 & Product or service choice & 3,98 & Baik \\
2 & Supplier choice & 3,50 & Baik \\
3 & Order quantities & 3,65 & Baik \\
4 & Delivery terms and times & 3,76 & Baik \\
5 & Service terms & 3,68 & Baik \\
6 & Payment & 3,77 & Baik \\
\hline & & 3,72 & Baik \\
\hline
\end{tabular}

Melalui tabel 2, rata-rata tertinggi adalah pemilihan produk dan jasa. Hal ini menunjukkan bahwa responden senang akan produk dan jasa makanan dan minuman di Bandung Utara. Nilai tinggi juga didapat dimensi delivery terms and times dan payment, yang berarti pelanggan merasa cukup fleksibel dari segi waktu membeli makanan dan minuman serta merasa mudah untuk melakukan pembayaran di restoran yang ada di Bandung Utara. Nilai rata-rata terendah adalah pada supplier choice, atau pemilihan restoran tempat makan hal ini berarti mereka tidak terpaut pada salah satu usaha jasa penyediaan makanan dan minuman di Bandung Utara. Secara keseluruhan keputusan pembelian tamu restoran di Bandung Utara sudah baik.

C. Peranan Kegiatan E-Word of mouth dalam Meningkatkan Keputusan Pembelian Tamu Restoran di Bandung Utara

Analisis data untuk mengetahui pengaruh electronic word of mouth terhadap keputusan pembelian dalam studi ini menggunakan analisis korelasi, koefisien determinasi, regresi dan uji signifikansi. Hasil dari pengujian analisis korelasi dan koefisien determinasi dapat terlihat pada tabel berikut ini.

TABEl 3. HASIL PERHITUNGAN KORELASI

\begin{tabular}{ccrrr}
\multicolumn{5}{c}{ Model Summary } \\
\hline Model & $\mathrm{R}$ & $\begin{array}{c}\mathrm{R} \\
\text { Square }\end{array}$ & $\begin{array}{c}\text { Adjusted R } \\
\text { Square }\end{array}$ & $\begin{array}{c}\text { Std. Error of } \\
\text { the Estimate }\end{array}$ \\
\hline 1 &, $689^{\mathrm{a}}$ &, 475 &, 459 & 2,666 \\
\hline
\end{tabular}

Hubungan electronic word of mouth dengan keputusan pembelian tamu restoran di Bandung Utara adalah kuat, hal ini dikarenakan nilai koefisien korelasinya 0,689. Dari persentase pengaruh, electronic word of mouth 47,5\% mempengaruhi keputusan pembelian, dan sisanya 52,5\% dipengaruhi oleh fakor lain. Adapun hasil perhitungan analisis regresi didapat persamaan sebagai berikut

$$
\mathrm{Y}=6,47+0,711 \mathrm{X} 1+0,425 \mathrm{X} 2+0,121 \mathrm{X} 3
$$

Keseluruhan dari nilai koefisien regresi menunjukkan bahwa seluruh sub variabel independent berpengaruh secara positif terhadap keputusan pembelian, namun sub variabel yang pengaruhnya paling tinggi dan satu-satunya yang signifikan pengaruhnya adalah sub variabel characteristic of the goods. Hal ini sesuai karena informasi yang paling banyak di dapat melalui electronic word of mouth adalah mengenai produk makanan dan minuman. Hasil dari uji signifikan secara simultan terlihat pada tabel berikut.

Hipotesis yang diajukan adalah:

$\begin{aligned} & \mathrm{H}_{0} \text { : Fhitung < Ftabel, } \text { Tidak terdapat } \\ & \text { pengaruh yang } \\ & \text { signifikan dari e-word } \\ & \text { of mouth terhadap } \\ & \text { keputusan pembelian } \\ & \text { tamu restoran di } \\ & \text { Bandung Utara. }\end{aligned}$

$\mathrm{H}_{\mathrm{a}}$ : Fhitung $>$ Ftabel, Terdapat pengaruh yang signifikan dari eword of mouth terhadap keputusan pembelian tamu restoran di Bandung Utara.

Nilai $\mathrm{F}$ tabel pada $\mathrm{db} 1=\mathrm{k}$ db2 $=(\mathrm{n}-\mathrm{k}-1)$ dan $\alpha=5 \%$ adalah 2,6994. Dengan begitu berarti Fhitung $=28,992>$ Ftabel $=2,6994$. Sehingga H0 ditolak dan Ha diterima, yaitu terdapat pengaruh yang signifikan dari e-word of mouth terhadap keputusan pembelian tamu restoran di Bandung Utara.

\section{KESIMPULAN}

Kegiatan electronic word of mouth akan restoran di Bandung Utara telah terlaksana dengan baik. Dalam kegiatan tersebut penyebaran informasi akan produk lebih tinggi dibandingkan dengan jasa dan penjualnya Secara keseluruhan keputusan pembelian tamu restoran di Bandung Utara sudah baik. Pelanggan senang akan produk dan jasa makanan dan minuman di Bandung Utara. Terdapat pengaruh yang signifikan dari e-word of mouth terhadap keputusan pembelian tamu 
restoran di Bandung Utara. Pengaruh tertinggi dan satu-satunya yang signifikan adalah dari characteristic of the goods

\section{DAFTAR RUJUKAN}

Ananda, Kun Sila. (2013, 21 Oktober). Jangan sering memotret makanan sebelum makan! [Online]. Tesedia:

http://www.merdeka.com/gaya/jangansering-memotret-makanan-sebelummakan.html [08 Maret 2015].

Cheung, Christy M.K., Lee, Matthew K.O., Rabjohn, Neil. (2008). The impact of electronic word-of-mouth: The adoption of online opinions in online customer communities. Internet Research, Vol. 18 Iss: 3, pp. $229-247$.

Hapsari, Deani Sekar. (2013, 08 Mei). Sering Unggah Gambar Makanan Bisa Jadi Gejala Gangguan Makan? [Online]. Tersedia:

http://food.detik.com/read/2013/05/08/081 208/2240721/297/sering-unggah-gambarmakanan-bisa-jadi-gejala-gangguanmakan [08 Maret 2015].

Hawkins, Del I. Mothersbaugh, David L. (2010). Consumer Behavior : Building Marketing Strategy 11th edition. New York : McGraw Hill.

Hollensen, Svend. (2010). Marketing Management, A Relationship Approach, 2nd Edition. England: Pearson Education Limited.

Kietzmann, Jan and Canhoto, Ana. (2013). Bittersweet! Understanding and Managing Electronic Word of mouth: Journal of Public Affairs. Published online in Wiley Online Library

Kotler, Philip and Armstrong, Gary. (2012). Principles of Marketing, 14th edition. United States of America: Pearson Prentice Hall

Kotler, Philip and Keller, Kevin Lane. (2012). Marketing Management 14th edition. New Jersey: Prentice-Hall International.
Litvin, S. W., Goldsmith, R. E., \& Pan, B. (2008). Electronic word-of-mouth in hospitality and tourism management. Tourism Management, 29, 458-468.

Nugraheni, Mutia. (2013, 09 Mei). Pamer Makanan di Media Sosial Bisa Jadi Tanda Gangguan Mental [Online]. Tesedia: http://life.viva.co.id/news/read/411552pamer-makanan-di-media-sosial-bisa-jaditanda-gangguan-mental [08 Maret 2015].

Silalahi, Ulber. (2012). Metode Penelitian Sosial. Bandung: Refika Aditama.

Song, K., Hwang, S., Kim, Y., \& Kwak, Y. (2013). The effects of social network properties on the acceleration of fashion information on the web. Multimedia Tools and Applications, 64(2), 455-474.

Sun, H. (2013). Moderating role of online word of mouth on website attributes and consumer trust in E-commerce environment. Journal of Applied Sciences, 13(12), 2316-2320.

Themba, Godfrey and Mulala, Monica. (2013). Brand-Related eWOM and Its Effects on Purchase Decisions: An Empirical Study of University of Botswana Students: International Journal of Business and Management; Vol. 8, No. 8.

Thomas Jr., G. (2004). Building the buzz in the hive mind. Journal of Consumer Behaviour, 4(1), 64-72.

Utama, I Gusti Bagus Rai dan Ni Made Eka Mahadewi. (2012). Metodologi Penelitian Pariwisata dan Perhotelan. Yogyakarta: Penerbit Andi.

Vilpponen, A., Winter, S. and Sundqvist, S. (2006). Electronic word-of-mouth in online environments: exploring referral network structure and adoption behavior. Journal of Interactive Advertising, Vol. 6, pp. 7186. 